\title{
The effectiveness of the Danish Organic Action Plan 2020 to increase the level of organic public procurement in Danish public kitchens
}

\author{
Nina N Sørensen ${ }^{1, *}$, Inge Tetens ${ }^{1}$, Hanne Løje ${ }^{2}$ and Anne D Lassen ${ }^{3}$ \\ 'Division of Diet, Disease Prevention and Toxicology, National Food Institute, Technical University of Denmark, \\ Mørkhøj Bygade 19, DK-2860 Søborg, Denmark: ${ }^{2}$ Division of Industrial Food Research, National Food Institute, \\ Technical University of Denmark, Kongens Lyngby, Denmark: ${ }^{3}$ Division of Risk Assessment and Nutrition, National \\ Food Institute, Technical University of Denmark, Søborg, Denmark
}

Submitted 3 November 2015: Final revision received 4 May 2016: Accepted 2 June 2016: First published online 4 July 2016

\begin{abstract}
Objective: To measure the effect of organic food conversion projects on the percentage of organic food used in Danish public kitchens participating in the Danish Organic Action Plan 2020.

Design: The current longitudinal study was based on measurements of organic food percentages in Danish public kitchens before and after kitchen employees participated in conversion projects.

Setting: Public kitchens participating in the nine organic food conversion projects under the Danish Organic Action Plan 2020, initiated during autumn 2012 and spring 2013 and completed in summer 2015.

Subjects: A total of 622 public kitchens.

Results: The average (median) increase in organic food percentage from baseline to follow-up was 24 percentage points $(P<0 \cdot 001)$ during an overall median follow-up period of 1.5 years. When analysing data according to public kitchen type, the increase remained significant for seven out of eight kitchens. Furthermore, the proportion of public kitchens eligible for the Organic Cuisine Label in either silver (60-90\% organic food procurement) or gold (90-100\% organic food procurement) level doubled from $31 \%$ to $62 \%$, respectively, during the conversion period. Conversion project curriculum mostly included elements of 'theory', 'menu planning', 'network' and 'Organic Cuisine Label method' to ensure successful implementation.

Conclusions: The study reports significant increases in the level of organic food procurement among public kitchens participating in the Danish Organic Action Plan 2020. Recommendations for future organic conversion projects include adding key curriculum components to the project's educational content and measuring changes in organic food percentage to increase the chances of successful implementation.
\end{abstract}

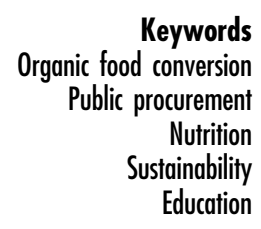

Organic food conversion projects targeting public kitchens have been developed and implemented in Denmark as well as internationally for more than two decades ${ }^{(1-3)}$. Organic food conversion has been suggested to affect not only the environmental sustainability of public procurement but also the diet compositions of the meals served in public kitchens by increasing the amounts of legumes, fruit and vegetables and reducing the amounts of meat and meat products used $^{(4-7)}$. Also reduced food waste and increased consumption of seasonal and local food products have been highlighted in relation to the potential benefits of organic food conversion to improve environmental sustainability within public procurement ${ }^{(8-10)}$.

These aspects formed part of the justification by the Danish Ministry of Food, Agriculture and Fisheries when launching the Danish Organic Action Plan 2020 in 2012 ${ }^{(11)}$, revised in $2015^{(12)}$. In accordance with the Action Plan for the future of Organic Production in the European Union $^{(13)}$, the Danish initiative aims to improve sustainability by stimulating the demand for Danish organic agriculture through a primary focus on increased public procurement of organic foods. The initiative therefore 
mainly targets organic food conversion projects through funding to implement educational training for public kitchen workers. No funding was available to cover the price premiums associated with organic food purchase.

A study on the effects on experienced well-being at work among public kitchen workers in relation to the organic food conversion projects implemented as part of the Danish Organic Action Plan 2020 has been published recently ${ }^{(14)}$. However, the effectiveness of such organic food conversion projects in increasing the level of organic procurement in public kitchens has not been scientifically documented despite previous calls ${ }^{(3,15)}$. With the wellknown and severe challenges faced by public kitchens during organic food conversion including unstable deliveries, challenging procurement policies and an increased premium price ${ }^{(16-18)}$, an evaluation of the level of success of the conversion projects in terms of specific measurements of organic food percentage in the public kitchens is needed ${ }^{(3)}$. Launched in 2009 by the Danish Veterinary and Food Administration, the Organic Cuisine Label method represents such specific and valid measurements ${ }^{(19)}$. The Organic Cuisine Label includes three labels based on the relative use of organic procurement: 30-60\% (bronze label), 60-90\% (silver label) and 90-100\% (gold label), based on procurement invoices, where the percentage interval 0-30\% does not qualify for a label. Also, further investigations into the educational content of the conversion projects will be valuable in terms of guiding future initiatives on potential best-practice training of public kitchen workers.

The primary objective of the present study was therefore to measure changes in organic food percentages in Danish public kitchens participating in organic food conversion projects under the Danish Organic Action Plan 2020 from autumn 2012 to spring 2013. Furthermore, the curriculum of the different organic food conversion projects was explored.

\section{Methods}

\section{Survey design and recruitment}

The present study was a longitudinal study measuring the organic food percentage in Danish public kitchens at baseline and follow-up during an organic food conversion project.

During autumn 2012 and spring 2013, a total of ten organic food conversion projects were selected by the Danish Agri-Fish Agency to receive funding within the Danish Organic Action Plan 2020. The public kitchens that participated in the ten projects were selected by the managers of the conversion projects based on their network and the political goals within the different municipalities.

Of the ten funded conversion projects including a total of 666 public kitchens, one project was excluded from the present study due to an extended conversion period compared with the remaining nine projects. As illustrated in Fig. 1, a total of 622 public kitchens included in the study completed both baseline and follow-up measurements. The public kitchen types were classified as childcare, school, afterschool, canteen, elderly, hospital, central or residential institution based on categories developed by the Danish Diet and Nutrition Association ${ }^{(20)}$. The median conversion period was 1.5 years (interquartile range $1.0-1.75$ years).

\section{Data collection}

According to the requirements for project funding, measurement of the organic food percentages by each public kitchen at baseline and follow-up using the Organic Cuisine Label method by the Danish Veterinary and Food Administration was mandatory ${ }^{(19)}$. This method is based on procurement invoices over a period of three months from suppliers to calculate the organic food percentage in either monetary value or weight ${ }^{(21)}$. More detailed description of the calculation method can be found elsewhere ${ }^{(22)}$. Some kitchens, especially at baseline, were however not able to apply the Organic Cuisine Label method and hence the Dogme method was accepted ${ }^{(23)}$. This method is an online tool based on self-reported organic food product use by kitchen workers, which has been found to have a high correlation with measurements from Organic Cuisine Label method except for the interval $55-75 \%$ where increased uncertainties have been identified ${ }^{(22)}$.

Organic food percentage measurements from each public kitchen were coupled to a background information survey answered by a representative from each public kitchen. The survey was developed and implemented

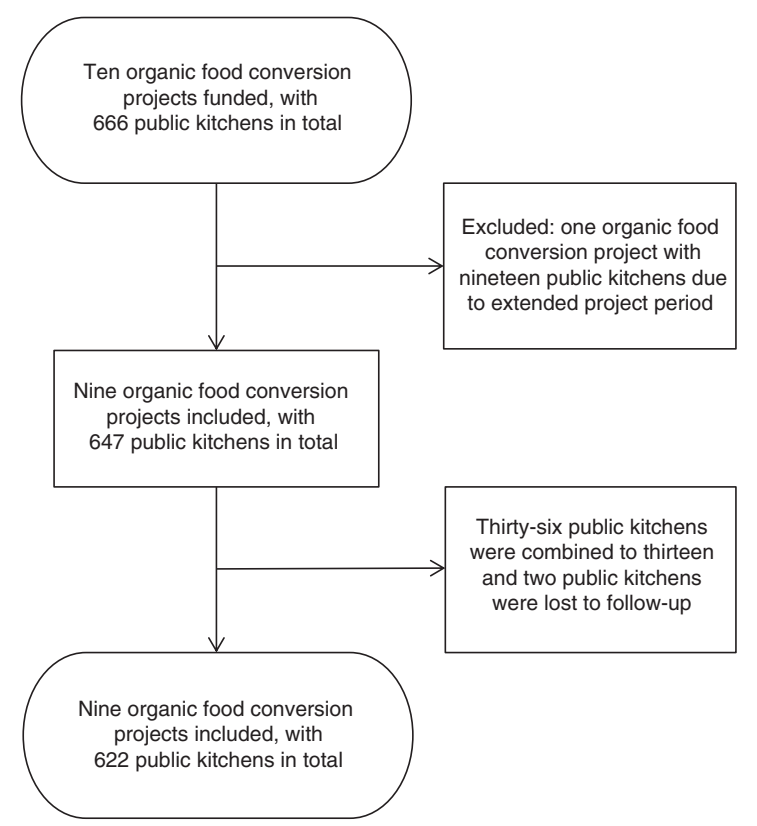

Fig. 1 Flowchart of the included organic food conversion projects and the participating public kitchens, Denmark, autumn 2012-spring 2013 to summer 2015 
by the research team and included information on the number of workers, consumers, meals produced and kitchen type for each kitchen.

To investigate potential differences in educational approach towards organic food conversion between the nine different conversion projects, project curriculum components were mapped by the research team. Information for the mapping originated from official descriptions of the individual conversion projects forming part of their funding applications.

\section{Outcomes}

The extent of organic food conversion from baseline to follow-up was defined as the change in the proportion of organic food used by the individual public kitchens. The differences in proportions of public kitchen with organic food percentages within the different intervals relevant for the Organic Cuisine Label (0-30\%, 30-60\%, 60-90\% and 90-100\%) were also reported. The measurement method applied was categorised as either the Organic Cuisine Label method or the Dogme method and unit as either monetary value or weight.

Based on prior experiences with organic food conversion $^{(8,15,24)}$ as well as informal dialogues with relevant conversion managers, the following twelve educational components were identified as either present or absent within each project:

1. Describe kitchen production system (identify focus areas).

2. Theory of organic food (production, health, environment).

3. Past experiences and success stories on conversion.

4. Practical cooking classes (local and seasonal).

5. Nutritional guidelines relevant for the kitchen users.

6. Menu planning with new production systems.

7. Budgeting for more organic food within previous budget.
8. Food-waste lessons on reuse of leftovers.

9. Field trips for kitchen workers to farms and producers.

10. Network between/among kitchens, suppliers and producers.

11. Organic Cuisine Label method introduction and application.

12. Follow-up visit offers to individual kitchen participants.

\section{Analysis}

The analyses were based on measurements of percentages of organic food used from baseline to follow-up. As data could not be considered normally distributed, nonparametric statistical hypothesis testing of differences between baseline and follow-up were made using the Wilcoxon signed-rank test (paired). This was done for all the public kitchens in total and for each kitchen type along with the median, first and third quartiles. The differences in proportions of public kitchens with organic food percentages within the percentage intervals of $0-30 \%$, $30-60 \%, 60-90 \%$ and $90-100 \%$ were treated as ordinal data and tested using $\chi^{2}$ tests.

Wilcoxon signed-rank (paired) and $\chi^{2}$ statistical analyses were done using the RStudio statistical software package version 0.98.1103 (R Inc., Boston, MA, USA).

\section{Results}

Of the 622 public kitchens, more than half were of the type childcare (56\%) followed by canteen (15\%) and elderly (10\%; Table 1). School and residential were both represented by $7 \%$, afterschool was represented by $3 \%$, and both hospital and central were represented by $1 \%$ each. However, in terms of main meals produced per week, central kitchens reported the highest proportion at

Table 1 Proportion of meals, kitchen users and workers in the eight different types of participating public kitchens across the nine included conversion projects, Denmark, autumn 2012-spring 2013 to summer 2015

\begin{tabular}{|c|c|c|c|c|c|}
\hline Kitchen type* & Kitchens (\%) & Workers (\%) & Kitchen users (\%) & Main meals $(\%) \dagger$ & Other (\%)‡ \\
\hline$n$ & 622 & 3505 & 69299 & 735317 & 387942 \\
\hline Childcare & 56 & 14 & 32 & 24 & 43 \\
\hline School & 7 & 3 & 9 & 3.5 & 6 \\
\hline Afterschool & 3 & 0 & 3 & 0.5 & 3 \\
\hline Canteen & 15 & 12 & 24 & 14 & 16 \\
\hline Elderly & 10 & 54 & 8 & 10 & 11 \\
\hline Hospital & 1 & 9 & 9 & 9 & 9 \\
\hline Central & 1 & 6 & 12 & 35 & 9 \\
\hline Residential & 7 & 2 & 3 & 4 & 3 \\
\hline
\end{tabular}

${ }^{*}$ Childcare includes all childcare institutions such as nurseries, kindergartens and integrated institutions; School includes school canteens and school cooking classes; Afterschool covers institutional after-school care; Canteen includes canteens or cafés associated with workplaces, universities, activity centres or cultural venues; Elderly includes homes for elderly; Hospital covers patient procurement; Central includes large-scale food production kitchens delivering procurement for receiving kitchens; Residential includes institutions in which consumers live permanently (i.e. social care facilities, university boarding schools and barracks).

†Total number of breakfasts, lunches and dinners produced per week, self-reported. Kitchen types open for production $5 \mathrm{~d} /$ week: childcare, school food, afterschool and canteen. Institution types open $7 \mathrm{~d} /$ week: elderly, hospital, central and residential.

¥Total number of snacks and in-between meals produced per week, self-reported. Kitchen types open $5 \mathrm{~d} /$ week: childcare, school, afterschool and canteen. Institution types open $7 \mathrm{~d} /$ week: elderly, hospital, central and residential. 
Table 2 Changes in organic food percentage across kitchen types from the nine different conversion projects during the organic food conversion period from baseline to follow-up, Denmark, autumn 2012-spring 2013 to summer 2015

\begin{tabular}{|c|c|c|c|c|c|c|c|c|}
\hline \multirow[b]{2}{*}{ Kitchen type } & \multirow[b]{2}{*}{$n$} & \multicolumn{2}{|c|}{ Baseline } & \multicolumn{2}{|c|}{ Follow-up } & \multicolumn{2}{|c|}{ Difference } & \multirow[b]{2}{*}{$P$ value $\dagger$} \\
\hline & & Median & IQR & Median & IQR & Median & IQR & \\
\hline All ${ }^{*}$ & 622 & 38 & $6-66$ & 69 & $48-83$ & 24 & $11-43$ & $<0.001$ \\
\hline Childcare & 349 & 59 & $40-78$ & 81 & 70-92 & 21 & $7-36$ & $<0.001$ \\
\hline School & 41 & 17 & $8-35$ & 49 & $26-58$ & 22 & $12-39$ & $<0.001$ \\
\hline Afterschool & 18 & 6 & $1-41$ & 40 & $6-54$ & 8 & $2-30$ & 0.163 \\
\hline Canteen & 91 & 3 & $0-15$ & 43 & $31-64$ & 35 & $24-45$ & $<0.001$ \\
\hline Elderly & 64 & 2 & $0-23$ & 51 & $41-65$ & 40 & $21-50$ & $<0.001$ \\
\hline Hospital & 7 & 1 & $1-29$ & 20 & $9-45$ & 16 & $1-19$ & 0.022 \\
\hline Central & 8 & 4 & $1-17$ & 40 & $31-55$ & 34 & $28-44$ & 0.016 \\
\hline Residential & 44 & 14 & $0-30$ & 53 & $41-64$ & 35 & $21-48$ & $<0.001$ \\
\hline
\end{tabular}

$\mathrm{IQR}$, interquartile range.

${ }^{*}$ Overall calculations included participating kitchens from all projects regardless of kitchen type.

†Wilcoxon signed-rank test (paired) using RStudio version 0.98.1103.

$35 \%$ followed by childcare (24\%), canteen (14\%), elderly (10\%), hospital (9\%), residential (4\%), school (3.5\%) and, lastly, afterschool (0.5\%).

\section{Change in organic food percentages}

As presented in Table 2, a significant increase in organic food percentage was identified for the total of 622 public kitchens from a median (interquartile range) of $38(6-66) \%$ at baseline to 69 (48-83) \% at follow-up $(P<0 \cdot 001)$, with a difference in medians of 24 percentage points. When calculating the overall organic food percentage per kitchen type at baseline and follow-up using average rather than median, the result was $22 \%$ at baseline and $47 \%$ at follow-up. Furthermore, significant increases in organic food percentage were identified for seven of the eight kitchen types $(P<0.05)$, whereas no change was observed for the afterschool kitchen type $(P=0 \cdot 16$; Table 2$)$.

Proportions of organic food percentages within the percentage intervals of $0-30 \%, 30-60 \%, 60-90 \%$ and 90-100\% were significantly different from baseline to follow-up $(P<0 \cdot 001$; Fig. 2$)$. The total number of kitchens in the $0-30 \%$ (no label) interval decreased from 270 at baseline to sixty-three kitchens at follow-up. Regarding the intervals for bronze, silver and gold, the number of kitchens increased from 162 to 174 (30-60\%, bronze), from 136 to 282 (60-90\%, silver) and from fifty-four to 103 (90-100\%, gold) from baseline to follow-up.

At baseline, $474(76 \%)$ of the public kitchens applied the Organic Cuisine Label method for organic food percentage measurements and this increased to 615 (99\%) at follow-up; the rest applied the Dogme method. In terms of reported measurement units, organic food percentages reported in kilograms increased from 511 (82\%) to 562 (90\%) from baseline to follow-up and the remaining were reported in monetary value (Danish Kroner).

\section{Organic food conversion project curriculum components}

Mapping the project curriculum of the nine organic food conversion projects showed that of the nine projects, five

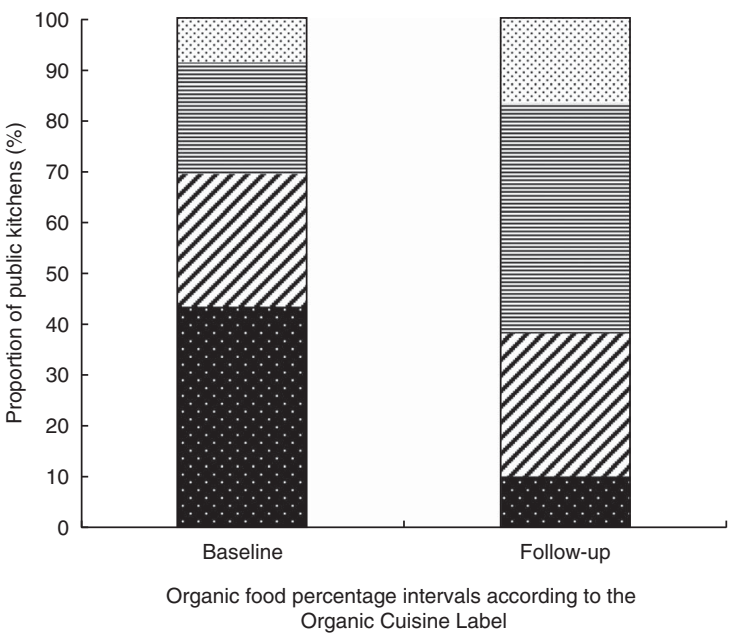

Fig. 2 Proportion of public kitchens participating in the organic food conversion projects with organic food percentages at the relevant intervals required for the Organic Cuisine Labels ( $[., 0-$ $30 \%$; 30-60\%; 目, 60-90\%; 团, 90-100\%) measured at baseline and end point ( $n$ 622), Denmark, autumn 2012-spring 2013 to summer 2015

were managed by producer associations, three by accounting companies and one was managed by a university (Table 3). All projects specifically described 'Theory of organic food (production, health, environment)', 'Menu planning with new production systems and routines', 'Network between/among kitchens, suppliers and producers' and 'Organic Cuisine Label method introduction and application' as part of the curriculum.

Eight out of nine projects also included 'Past experiences and success stories on conversion', 'Practical cooking classes (local and seasonal)', 'Nutritional guidelines relevant for the kitchen users', 'Budgeting for more organic food within previous budget' and 'Food-waste lessons on reuse of leftovers'. Seven projects included 'Describe kitchen production system (identify focus areas)', six projects included 'Field trips for kitchen workers to farms and producers' and only two projects included 'Follow-up visit offers to individual kitchen participants'. 
Table 3 Organic food conversion curriculum components included in the nine conversion projects implemented with funding from the Danish Organic Action Plan 2020 targeting public kitchens, Denmark, autumn 2012-spring 2013 to summer 2015

\begin{tabular}{|c|c|c|c|c|c|c|c|c|c|}
\hline \multirow[b]{2}{*}{ Project educational content components } & \multicolumn{9}{|c|}{ Conversion projects* } \\
\hline & 1 & 2 & 3 & 4 & 5 & 6 & 7 & 8 & 9 \\
\hline Describe kitchen production system (identify focus areas) & & $\mathrm{X}$ & $\mathrm{X}$ & & $\mathrm{X}$ & $\mathrm{X}$ & $\mathrm{x}$ & $\mathrm{X}$ & $\mathrm{X}$ \\
\hline Theory of organic food (production, health, environment) & $\mathrm{X}$ & $\mathrm{x}$ & $X$ & $\mathrm{X}$ & $X$ & $X$ & $X$ & $\mathrm{x}$ & $\mathrm{X}$ \\
\hline Past experiences and success stories on conversion & $\mathrm{X}$ & $x$ & $\mathrm{X}$ & & $\mathrm{X}$ & $\mathrm{X}$ & $\mathrm{X}$ & $x$ & $\mathrm{x}$ \\
\hline Practical cooking classes (local and seasonal) & & $\mathrm{X}$ & $\mathrm{X}$ & $\mathrm{X}$ & $\mathrm{X}$ & $\mathrm{X}$ & $\mathrm{X}$ & $\mathrm{X}$ & $\mathrm{x}$ \\
\hline Nutritional guidelines relevant for the kitchen users & & $\mathrm{X}$ & $\mathrm{X}$ & $\mathrm{X}$ & $\mathrm{X}$ & $\mathrm{X}$ & $\mathrm{X}$ & $\mathrm{X}$ & $\mathrm{X}$ \\
\hline Menu planning with new production systems & $\mathrm{X}$ & $\mathrm{x}$ & $\mathrm{X}$ & $\mathrm{X}$ & $\mathrm{X}$ & $\mathrm{X}$ & $\mathrm{X}$ & $\mathrm{x}$ & $\mathrm{X}$ \\
\hline Budgeting for more organic food within previous budget & & $\mathrm{x}$ & $\mathrm{X}$ & $\mathrm{X}$ & $\mathrm{X}$ & $\mathrm{X}$ & $\mathrm{X}$ & $\mathrm{X}$ & $\mathrm{X}$ \\
\hline Food-waste lessons on reuse of leftovers & & $\mathrm{X}$ & $\mathrm{X}$ & $\mathrm{X}$ & $\mathrm{X}$ & $\mathrm{X}$ & $\mathrm{X}$ & $\mathrm{X}$ & $\mathrm{X}$ \\
\hline Field trips for kitchen workers to farms and producers & $\mathrm{X}$ & & & $\mathrm{X}$ & $\mathrm{X}$ & $\mathrm{X}$ & & $\mathrm{x}$ & $\mathrm{x}$ \\
\hline Network between/among kitchens, suppliers and producers & $\mathrm{X}$ & $\mathrm{X}$ & $\mathrm{X}$ & $\mathrm{X}$ & $\mathrm{X}$ & $\mathrm{X}$ & $\mathrm{X}$ & $\mathrm{X}$ & $\mathrm{x}$ \\
\hline Organic Cuisine Label method introduction and application & $\mathrm{X}$ & $\mathrm{X}$ & $\mathrm{X}$ & $\mathrm{X}$ & $\mathrm{X}$ & $\mathrm{X}$ & $\mathrm{X}$ & $\mathrm{x}$ & $\mathrm{X}$ \\
\hline Follow-up visit offers to individual kitchen participants & & & $\mathrm{X}$ & & & & $\mathrm{X}$ & & \\
\hline
\end{tabular}

*Managing institution: 1, 3, 5, 7 and $8=$ producer association; 2, 6 and $9=$ audit, accounting and counselling company; $4=$ university.

\section{Discussion}

Results from the present study showed an average (median) increase in the organic food percentage from baseline to follow-up of 24 percentage points. This significant increase was also illustrated by a significant shift in Organic Cuisine Label eligibility, approximately doubling the number of kitchens eligible for either silver (60-90\%) or gold (90-100\%) label from 190 to 385. The mapping of conversion project curriculum revealed that components on 'theory', 'menu planning', 'network' and 'Organic Cuisine Label method' were prioritised by all nine projects.

Despite the relatively long history of organic food conversion in Danish public kitchens, the current study is the first to meet the call from previous research ${ }^{(3,15)}$ and present data on the organic food used in public kitchens during organic food conversion projects through strictly regulated Organic Cuisine Label method measurements ${ }^{(25)}$. Related European initiatives on organic public procurement have explored similar settings and intentions as the Danish Organic Action Plan 2020 ${ }^{(26-29)}$, but no studies documenting measurements of organic food use comparable with the results presented here have been found.

Regarding conversion project curriculum, components included by all nine or eight projects could be considered key components for a successful implementation of organic food procurement in public kitchens. Results from past experiences highlight similar elements in their description of important steps towards organic food conversion $^{(6,30)}$. The theory component allows for kitchen workers to understand the differences between organic and conventional food production, where practical classes enable the workers to familiarise themselves with and prepare organic meals made from local and seasonal raw foodstuffs rather than convenience products ${ }^{(15)}$.

Menu planning, budgeting and food-waste management are necessary to optimise the food production in the kitchen and save resources that can cover the premium prices of organic food ${ }^{(16)}$. For instance, food-waste reductions during an organic food conversion project have been reported earlier ${ }^{(10)}$, although this was not evaluated in the present study. Including nutritional guidelines in the educational content ensures that the reformulated organic meals cover the nutritional needs of the kitchen users, whether that would be children, elderly or hospitalised patients ${ }^{(5,31-33)}$. Implementation of this component during organic food conversion has also been suggested by kitchen workers earlier ${ }^{(14)}$. Also components on networking, past success stories and the Organic Cuisine Label method were important to the conversion projects. According to recent evaluations, networking platforms are important to improve communication among kitchens and suppliers, whereas past success stories and introducing the labels help motive and anchor the implementation of organic food use after the conversion project ends ${ }^{(8,24)}$. This view might be supported by the increased application of the Organic Cuisine Label method at follow-up (99\%), potentially indicating a development within the participating public kitchens during the organic food conversion process in terms of increased awareness and motivation towards acquiring the Organic Cuisine Label.

Describing the kitchen production system to identify possible barriers and opportunities for increasing the organic procurement, field trips and follow-up visits were components included less often in the conversion projects. Indications from the conversion managers and former qualitative interviews suggest that the purpose of the components was to identify potential focus areas for organic food conversion and to motivate kitchen workers ${ }^{(24)}$. However, these may have been left out due to time and budget restrictions within the conversion projects or incorporated in other ways in the projects.

This knowledge of the conversion project curriculum illustrates a high level of complexity within the implementation of organic food procurement in public kitchens. 
Conversion projects seem to design and tailor a lot of the educational content according to kitchen type, size, nutritional needs of the kitchen user group, economic budget limitations in the kitchen and sustainability of both the conversion in itself after the project ends as well as the environmental sustainability. The key components discussed above seem to be interrelated to a degree where the project simply would not be possible to implement without considering them all. In this view, organic food conversion appears to be tightly linked to sustainability and public health. Increased organic public procurement supports organic food production, which in itself has been shown to be more sustainable in terms of productivity, environmental impact, economic viability and social well-being ${ }^{(34,35)}$. Furthermore, the discussion above confirms the presence of important sustainability aspects in the conversion project content such as more environmental awareness of the kitchen workers, increased use of local and seasonal food products and limited food waste, which is supported by earlier studies $^{(8,15,24)}$.

In terms of public health nutrition, most conversion projects in the present study included educational training on 'Nutritional guidelines relevant for the kitchen users'. Although the study did not evaluate changes in meal composition within the public kitchens during the conversion projects, the presence of this component could suggest that the nutritional needs of the kitchens users will not be compromised as a result of the conversion project. In fact, organic food conversion has been suggested to result in meal compositions more in line with recommendations ${ }^{(5,32)}$, which is supported by other findings ${ }^{(36)}$.

Also, an increasingly important aspect to consider in the public health discussion is the dietary exposure to pesticides, fertilisers, antibiotics and other chemicals ${ }^{(37)}$, which may have severe adverse effects on human reproductive and child health ${ }^{(38,39)}$ and that can be avoided through organic food consumption ${ }^{(40-42)}$. However, it should be noted that pesticide application in Denmark is already tightly regulated even in conventional food production with low dietary residue levels ${ }^{(43,44)}$ and so the national impact of lower pesticide application in food production might not be as significant as in other EU countries $^{(45)}$.

In terms of national impact on organic food production, the increase in organic public procurement found in the present study could be extensive over time as the sample size of 622 public kitchens out of approximately 6000-10000 public kitchens in total in Denmark can be considered relatively large ${ }^{(46)}$. However, the potential also remains substantial. The revision of the Danish Organic Action Plan 2020 in 2015 did not affect the organic food conversion projects included in the present study, but changed application details for future conversion projects ${ }^{(12)}$.
Limitations to the current study include the lack of control public kitchens that were not exposed to the organic food conversion process, which renders the results unable to directly infer causality. Also selection bias cannot be excluded because the public kitchens were not randomly selected for the conversion projects. However, a number of points from the study argue for a high level of transferability of the organic food conversion projects within Denmark as well as internationally. First, although the public kitchen sample in the present study is not representative of the total group of public kitchens in Denmark, the results suggest that organic food conversion was implemented successfully across different public kitchen types and procurement settings. Second, due to the project funding requirements of the Danish Organic Action Plan 2020, loss to follow-up of public kitchen participation was limited. The observed increase in organic food percentages is therefore likely to be true as all public kitchens reported on their progress regardless of the extent of their achievement, minimising the threat of introducing bias. Lastly, a number of participating public kitchens were recruited to a conversion project following top-down political decision making at municipality level rather than actively seeking conversion project recruitment independently. This fact also shows that the study sample at baseline did not consist only of highly motivated public kitchens and still conversion projects successfully implemented organic procurement. In sum, nothing argues against the possibility of reproducing similar results with a similar initiative in Denmark or abroad.

In order to evaluate conversion project content, additional qualitative interviews with project managers and kitchen worker participants could have been interesting to include as well as observations during conversion project implementation in combination with the mapping of curriculum components. Measures of change to the nutritional composition of the public meals, food waste and kitchen user satisfaction would also be valuable to include in future research.

\section{Conclusion}

In conclusion, the present study reports significant increases in the percentage of organic food procurement with a difference in medians of 24 percentage points among 622 participating public kitchens during a median conversion period of 1.5 years, along with a significant shift in the number of public kitchens eligible for Organic Cuisine Labels at the silver and gold level. Hence, the results indicate significant effects of organic food conversion projects on increasing the organic food percentage in public kitchens within their existing budgets. The mapping of curriculum components of the conversion projects identified key components in terms of theory, menu planning, networking, Organic Cuisine Label 
method, past success stories, practical training, nutritional guidelines, budgeting and food-waste managing, which may be associated with improved nutrition and sustainability. These results represent new research supporting future implementation of initiatives similar to the Danish Organic Action Plan 2020.

\section{Acknowledgements}

Acknowledgements: The authors wish to thank all participating public kitchens and organic food conversion projects for contributing to this study. Financial support: This work was supported by the Danish Veterinary and Food Administration and the National Food Institute, Technical University of Denmark. The Danish Veterinary and Food Administration had no role in the design, analysis or writing of this paper. Conflict of interest: None. Authorship: All authors were involved in formulating the research questions, designing the study, analysing data and editing article drafts. N.N.S. had a primary role in collecting data, analysing data and writing the article. Ethics of human subject participation: No ethical approval needed.

\section{References}

1. Mikkelsen B (1993) Organic foods in catering. Nutr Food Sci 93, 24-26.

2. Raunkjær K (1997) Organic foods in hospital kitchens in the public sector. Constraints and oppertunities illustrated by current cases from Denmark. PhD Thesis, Technical University of Denmark.

3. The Danish Agri-Fish Agency (2004) Evaluering af tilskudsordningen Grønne Indkøb: økologiske fødevarer $i$ offentlige institutioner og storkøkkener (Evaluation Report of the Scheme: Green Shopping - Organic Shopping in Public Institutions and Commercial Kitchens). Aarhus: The Danish Agri-Fish Agency.

4. Jensen KOD, Mølgaard JP, Andersen J et al. (2001) Økologiske fødevarer og menneskets sundhed: rapport fra vidensyntese udført $i$ regi af Forskningsinstitut for Human Ernaering, KVL (Organic Food and Health: Knowledge-Synthesis Report Conducted Under Auspices of the Department of Nutrition, $K V L)$. Tjele: Forskningscenter for $\varnothing$ kologisk Jordbrug.

5. Mikkelsen B, Bruselius-Jensen M, Andersen J et al. (2006) Are green caterers more likely to serve healthy meals than non-green caterers? Results from a quantitative study in Danish worksite catering. Public Health Nutr 9, 846-850.

6. International Centre for Research in Organic Food Systems (2008) Udvikling, vaekst og integritet $i$ den danske økologisektor: vidensyntese (Development, Growth and Integrity in the Danish Organic Sector: Knowledge-Synthesis). Tjele: ICROFS.

7. He C \& Mikkelsen BE (2014) The association between organic school food policy and school food environment: results from an observational study in Danish schools. Perspect Public Health 134, 110-116.

8. Madkulturen \& Aalborg University (2013) Kvalitativ undersøgelse af økologi $i$ offentlige køkkener - fra beslutning til praksis (Qualitative Study on Organic Food in Public Kitchens: From Decision-Making to Practice). Roskilde: Madkulturen \& Aalborg University.
9. United Nations Conference on Trade and Development (2013) Trade and Environment Review 2013: Wake Up Before It Is Too Late. Geneva: UNCTAD.

10. Thorsen AV, Sabinsky M \& Trolle E (2014) Madspild $i$ forbindelse med økologi- omlagning $i$ offentlige køkkener (Food Waste During Organic Food Conversion in Public Kitchens). Søborg: DTU National Food Institute.

11. Danish Ministry of Food, Agriculture and Fisheries (2012) Økologisk Handlingsplan 2020 (The Danish Organic Action Plan 2020). Copenhagen: Danish Ministry of Food, Agriculture and Fisheries.

12. Danish Ministry of Food Agriculture and Fisheries (2015) Økologiplan Danmark: sammen om mere økologi (Organic Plan Denmark: Together Towards More Organic). Copenhagen: Danish Ministry of Food Agriculture and Fisheries.

13. European Commission (2014) Action Plan for the Future of Organic Production in the European 26. Brussels: European Commission.

14. Sørensen NN, Løje H, Tetens I et al. (2016) Wellbeing at work among kitchen workers during organic food conversion in Danish public kitchens: a longitudinal survey. Eur J Public Health 26, 323-328.

15. Mikkelsen B \& Sylvest J (2012) Organic foods on the public plate: technical challenge or organizational change? J Foodserv Bus Res 15, 64-83.

16. Mikkelsen B, Kristensen N \& Nielsen $T$ (2005) Innovation processes in large-scale public foodservice - case findings from the implementation of organic foods in a Danish county. J Foodserv Bus Res 8, 87-105.

17. Walker H \& Brammer S (2009) Sustainable procurement in the United Kingdom public sector. Supply Chain Manage 14, 128-137.

18. Pedersen $\mathrm{AB}$ \& Jensen A (2016) Brugerundersøgelse og videreudvikling af rådgivning $i$ kloge fødevareindkøb (User Survey and Development of Advice for Wise Food Shopping). Aarhus: University of Aarhus.

19. Danish Veterinary and Food Administration (2014) Vejledning om økologisk storkøkkendrift (Guidance Report on Organic Procurement in Catering Kitchens). Copenhagen: Danish Veterinary and Food Administration.

20. Christiansen J \& El-Salanti N (2000) På fuldt blus 2000 (Full Speed 2000). Copenhagen: Centre for Alternative Societal Analysis.

21. Danish Veterinary and Food Administration (2009) Det $\varnothing$ kologiske spisemærke (The Organic Cuisine Label). http:// www.oekologisk-spisemaerke.dk/ (accessed May 2016).

22. Sørensen N, Lassen A, Løje H et al. (2015) The Danish Organic Action Plan 2020: assessment method and baseline status of organic procurement in public kitchens. Public Health Nutr 18, 2350-2357.

23. Green Cities (2005) Måling af indkøb (Measuring procurement). http://madstatus.helptool.dk/t2w_1.asp (accessed May 2016).

24. NIRAS (2014) Erfaringsopsamling mbt. redskaber og undervisningsmateriale til økologiomlagning $i$ offentlige køkkener (Experiences with Tools and Educational Materials in Relation to Organic Food Conversion in Public Kitchens). Copenhagen: Danish Veterinary and Food Administration.

25. Strassner C, Lukas M \& Løes A (2010) Certification of Public Organic Procurement in Denmark, Finland, Italy and Norway as Compared to Germany. Bioforsk Report, vol. 5 , no. 103. Tingvoll: Bioforsk.

26. Rech T (2003) Organic food for public institutions. In Organic Agriculture: Sustainability, Markets and Policies, pp. 401-406. Wallingford: CAB International and Organisation for Economic Co-operation and Development.

27. Bårdsen MG \& Løes A (2010) Organic Food in Schools and Kindergartens in Trondheim: A Case Study Report. Bioforsk Report, vol. 5, no. 18. Tingvoll: Bioforsk. 
28. Løes A \& Nölting B (2011) Increasing organic consumption through school meals - lessons learned in the iPOPY project. Agron Res 1, 91-110.

29. Tikkanen I (2012) Steps towards an organic professional kitchen. Nutr Food Sci 42, 181-188.

30. Elle J, Jensen M \& Mikkelsen B (2006) Projekt Basiskost: sunde og økologiske fødevarer $i$ storkøkkener (Project Core-Diet: Healthy and Organic Food in Catering Kitchens). Søborg: Danmarks Fødevareforskning.

31. Danish Veterinary and Food Administration (2007) Råd om mad og motion: når du bliver aldre (Guidance on Food and Exercise: When You Get Older). Copenhagen: Danish Veterinary and Food Administration.

32. Danish Veterinary and Food Administration (2013) De officielle kostråd (The Official Dietary Advice). Glostrup: Danish Veterinary and Food Administration.

33. Danish Health Authority (2015) Ernoering til spaedbørn og småbørn - en håndbog for sundhedspersonale (Nutrition for Babies and Toddlers - A Handbook for Health Professionals). Copenhagen: Danish Health Authority.

34. International Centre for Research in Organic Food Systems (2015) Økologiens bidrag til samfundsgoder: vidensyntese 2015 (Organic Contributions to Public Goods: Knowledge Synthesis). Tjele: ICROFS.

35. Reganold J \& Wachter J (2016) Organic agriculture in the twenty-first century. Nat Plants 2, 15221.

36. Torjusen H, Lieblein G, Næes T et al. (2012) Food patterns and dietary quality associated with organic food consumption during pregnancy; data from a large cohort of pregnant women in Norway. BMC Public Health 12, 612.

37. Smith-Spangler C, Brandeau ML, Hunter GE et al. (2012) Are organic foods safer or healthier than conventional alternatives? A systematic review. Ann Intern Med 157, 348-366.

38. Torjusen H, Brantsaeter AL, Haugen M et al. (2014) Reduced risk of pre-eclampsia with organic vegetable consumption: results from the prospective Norwegian Mother and Child Cohort Study. BMJ Open 4, e006143.

39. Brantsæter AL, Torjusen H, Meltzer HM et al. (2016) Organic food consumption during pregnancy and hypospadias and cryptorchidism at birth: the Norwegian Mother and Child Cohort Study (MoBa). Environ Health Perspect 124, 357-364.

40. Lu C, Toepel K, Irish R et al. (2006) Organic diets significantly lower children's dietary exposure to organophosphorus pesticides. Environ Health Perspect 114, 260-263.

41. Lu C, Barr DB, Pearson MA et al. (2008) Dietary intake and its contribution to longitudinal organophosphorus pesticide exposure in urban/suburban children. Environ Health Perspect 116, 537-542.

42. Oates L, Cohen M, Braun L et al. (2014) Reduction in urinary organophosphate pesticide metabolites in adults after a week-long organic diet. Environ Res 132, 105-111.

43. The Danish Ministry of the Environment (2013) Protect Water, Nature and Human Health: Pesticides Strategy 2013-2015. Copenhagen: Danish Ministry of the Environment.

44. DTU National Food Institute \& Danish Veterinary and Food Administration (2015) Pesticidrester $i$ fødevarer 2014: resultater fra den danske pesticidkontrol (Pesticide Residues in Foods 2014: Results from the National Pesticide Control). Glostrup: DTU National Food Institute and Danish Veterinary and Food Administration.

45. European Food Safety Authority (2015) The 2013 European Union report on pesticide residues in food. EFSA $J \mathbf{1 3}$, $1-169$.

46. Ministry of Environment and Food of Denmark \& Danish Veterinary and Food Administration (2015) Øko 25 år: FVM factfile (Organic 25 Years: Factsheet). Copenhagen: Ministry of Environment and Food of Denmark and Danish Veterinary and Food Administration. 